\title{
A survey of agricultural pests and predators on cole crops in Kanpur region, Uttar Pradesh, India
}

\author{
NEELAM YADAV* AND NEERJA AGRAWAL
}

Department of Entomology, Chandra Shekhar Azad University of Agriculture and Technology, KANPUR (U.P.) INDIA

\section{ARITCLE INFO}

Received : 23.01 .2017

Revised : 25.08 .2017

Accepted : 07.09.2017

\section{KEY WORDS :}

Pests, Predators, Cole crops

*Corresponding author: Email: neelu.amogh@gmail.com

\begin{abstract}
:
The study was conducted from October to December 2015 in Kanpur region, U.P. to survey on agricultural pests and predators on cole crops (cabbage and cauliflower).Cole crops are a large and increasingly important crop groups. A number of insects feed exclusively on cole crops and affect all of the crops. A survey was conducted at four sites (COD, Katri, Pukhrayan and Ghatampur) in Kanpur region and inspected in two types of field i.e. insecticides sprayed field and organic field (unsprayed). The present study resulted that a small number of predators and some pests were found in pesticides sprayed field of cole crops due to chemical pesticides and in organic field large quantity of predators but few pests were recorded in cole crops. These crops were the focus of the study because they are locally important to organic growers.
\end{abstract}

How to view point the article : Yadav, Neelam and Agrawal, Neerja (2017). A survey of agricultural pests and predators on cole crops in Kanpur region, Uttar Pradesh, India. Internat. J. Plant Protec., 10(2) : 360-363, DOI : 10.15740/HAS/IJPP/10.2/360-363. 